\title{
The Effect of Okra (Abelmoschus esculentus (L.) Moench) Seed Extract on Human Cancer Cell Lines Delivered in Its Native Form and Loaded in Polymeric Micelles
}

\author{
Watcharaphong Chaemsawang, ${ }^{1}$ Weerapong Prasongchean, ${ }^{2}$ \\ Konstantinos I. Papadopoulos $\mathbb{D}$, ${ }^{3}$ Garnpimol Ritthidej, ${ }^{1}$ Suchada Sukrong $\mathbb{D},{ }^{4,5}$ \\ and Phanphen Wattanaarsakit $\mathbb{D}^{1}$ \\ ${ }^{1}$ Department of Pharmaceutics and Industrial Pharmacy, Faculty of Pharmaceutical Sciences, Chulalongkorn University, \\ 254 Phyathai Road, Pathumwan, Bangkok 10330, Thailand \\ ${ }^{2}$ Department of Biochemistry and Microbiology, Faculty of Pharmaceutical Sciences, Chulalongkorn University, \\ 254 Phyathai Road, Pathumwan, Bangkok 10330, Thailand \\ ${ }^{3}$ THAI StemLife, 566/3 Soi Ramkhamhaeng 39 (Thepleela 1), Prachaouthit Rd, Wang Thonglang, Bangkok 10310, Thailand \\ ${ }^{4}$ Department of Pharmacognosy and Pharmaceutical Botany, Faculty of Pharmaceutical Sciences, Chulalongkorn University, \\ 254 Phyathai Road, Pathumwan, Bangkok 10330, Thailand \\ ${ }^{5}$ Research Unit of DNA Barcoding of Thai Medicinal Plants, Faculty of Pharmaceutical Sciences, Chulalongkorn University, \\ 254 Phyathai Road, Pathumwan, Bangkok 10330, Thailand
}

Correspondence should be addressed to Phanphen Wattanaarsakit; aphanphe@chula.ac.th

Received 30 May 2019; Revised 18 August 2019; Accepted 6 September 2019; Published 21 October 2019

Academic Editor: Wen-Cheng Chen

Copyright (c) 2019 Watcharaphong Chaemsawang et al. This is an open access article distributed under the Creative Commons Attribution License, which permits unrestricted use, distribution, and reproduction in any medium, provided the original work is properly cited.

\begin{abstract}
Cancer is a noncommunicable disease with a high worldwide incidence and mortality rate. The National Cancer Institute of Thailand reports increasing cumulative incidence of breast, colorectal, liver, lung, and cervical cancers, accounting for more than $60 \%$ of all cancers in the kingdom. In this current work, we attempt to elucidate the phytochemical composition of the okra (Abelmoschus esculentus (L.) Moench) seed extract (OSE) and study its anticancer activity, delivered in its native form as well as in the form of polymeric micelles with enhanced solubility, in three carcinoma cell lines (MCF-7, HeLa, and HepG2). The presence of flavonoid compounds in the OSE was successfully confirmed, and direct delivery had the highest cytotoxic effect on the breast cancer cell line (MCF-7), followed by the hepatocellular carcinoma (HepG2) and cervical carcinoma (HeLa) cell lines in that order, while its delivery in polymeric micelles further increased this effect only in the HepG2 cell line. The OSE's observed cytotoxic effects on cancer cell lines demonstrated a dose and time-dependent cell proliferation and migration inhibition plausibly due to VEGF production inhibition, leading to apoptosis and cell death, conceivably due to the four flavonoid compounds noted in the current study, one of which was isoquercitrin. However, in view of the latter compound's isolated effects being inferior to those observed by the OSE, we hypothesize that either isoquercitrin requires the biological synergy of any one or all of the observed flavonoids or any of the three in isolation or all in concert are responsible. Further studies are required to elucidate the nature of the three unknown compounds. Furthermore, as we encountered significant problems in dissolving the okra seed extract and creating the polymeric micelles, further studies are needed to devise a clinically beneficial delivery and targeting system.
\end{abstract}

\section{Introduction}

Cancer is a noncommunicable disease with a high worldwide incidence and mortality rate [1-3]. The National Cancer
Institute of Thailand reports increasing cumulative incidence of breast, colorectal, liver, lung, and cervical cancers, accounting for more than $60 \%$ of all cancers in the kingdom. In this current work, we focus on three cancer types, breast 
and cervical cancer with the highest incidence in Thai women, while liver cancer has the highest cancer mortality rate in Thailand.

Abelmoschus esculentus (L.) Moench (okra) is a flowering plant in the Malvaceae family. Since okra pods are edible, the okra plant, a native to Africa, is planted in many tropical and subtropical regions around the world, such as Southeast Asia, the Indian subcontinent, and the Mediterranean. In folk medicine, okra is commonly used to treat gastritis. Pharmacological studies have highlighted its antioxidant, neuroprotective, antidiabetic, antihyperlipidemic, and anti-fatigue activities [4]. Okra pods have previously been shown to contain high contents of polysaccharides, polyphenols, and flavonoids. The latter two possess strong antioxidant effects $[5,6]$ and emanate from the okra seeds while its skin extract hardly displayed such reactions. A substance frequently mentioned in the okra seed extract is isoquercitrin, with higher bioavailability than quercetin, displaying a number of chemoprotective effects both in vitro and in vivo, against oxidative stress, cardiovascular disorders, diabetes, allergic reactions, and cancer [7]. Isoquercitrin has shown inhibition of urinary bladder and pancreatic cancer progress $[8,9]$, as well as colon cancer suppression [10]. Despite the above numerous mentions, there is a paucity of reports regarding the anticancer effects of okra seeds. Solubility issues pertaining to flavonoid compounds necessitate a delivery system to increase cellular uptake and cytoplasm accessibility. One of the most promising delivery systems is the polymeric micelles, due to the easiness and low cost of preparation [11-14].

The aim of the present study was to elucidate the phytochemical composition of the okra seed extract and study the anticancer activity of its flavonoid-rich fraction, delivered in its native form as well as in the form of a polymeric micelle with enhanced solubility, in three carcinoma cell lines.

\section{Materials and Methods}

2.1. Chemicals and Reagents. Isoquercitrin (quercetin 3-Oglucoside) of $90 \%$ purity and poloxamer 407 bioreagent grade [9003-11-6] were purchased from Sigma-Aldrich, while Dulbecco's modified Eagle's medium (DMEM) and Roswell Park Memorial Institute (RPMI) 1640 medium were purchased from Biowest. Fetal bovine serum (FBS), L-glutamax, and antibiotic/antimycotic were purchased from Invitrogen. HPLC reagents, standards, and solvents were of Analytical Reagent (AR) grade and purchased from SigmaAldrich. Ferric chloride reagent and Folin-Ciocalteu reagent were purchased from Merck Millipore.

2.2. Preparation of Okra Seed Extracts. Okra pods grown locally in Nakhon Pathom province in Thailand were purchased at the Pathom Mongkol market in the same province and were in a state of maturity, ready to be prepared for human consumption. The method of extraction used in our work was modified from the method of Adetuyi and Ibrahim [15]. The seeds were separated from their fruit before maceration with $95 \%$ ethanol for $24 \mathrm{hrs}$. The macerated solution was filtered and evaporated using an evaporator. The concentrate was dried using a lyophilizer (Labconco) (Figure 1). The crude okra seed extract was stored at $-20^{\circ} \mathrm{C}$ without exposure to light until used.

\subsection{Qualitative and Quantitative Analysis of Phytochemicals.} The composition of the extract was screened by using a partition method before testing as per the below described method. The okra seed extract (OSE) was partitioned with hexane : ethanol: water in the ratio $50: 45: 5$. The ethanol layer was further partitioned with dichloromethane: ethanol: water in the ratio $50: 30: 20$. Each fraction was let to evaporate, (OSEHex, OSE-DCM, and OSE-EtOH) before chemical testing.

2.3.1. Phytochemical Screening. Phytochemical screening of okra seed extract, ethanol, and dichloromethane and petroleum fraction of okra seeds were performed for the qualitative detection of different phytochemicals such as alkaloids, flavonoids, saponins, glycosides, phenols, and tannin. All phytochemical tests were performed according to the standed methods described by Samejo et al. [16] and Maria et al. [17].

2.3.2. Determination of Total Phenolic Content. Total phenolic contents (TP) in different seed extracts of okra seeds were determined using a modified Folin-Ciocalteu (FC) colorimetric method [18-20]. In short, $25 \mu \mathrm{l}$ of the extract was mixed with $75 \mu \mathrm{l}$ deionized water in 96-well plates, and then, $1: 1 \mathrm{FC}$ reagent was added and incubated in the dark for 6 minutes. Following this, $100 \mu \mathrm{l}$ of $7.5 \% \mathrm{Na}_{2} \mathrm{CO}_{3}$ was added, and the solution was incubated in the dark for another $90 \mathrm{~min}$. The phenolic content is then measured using a microplate reader at $765 \mathrm{~nm}$ wavelength carried out using a standard solution of gallic acid, reported as gallic acid equivalents (GAE)/gram dry weight extract.

2.3.3. Determination of Total Flavonoid Content. The total flavonoid content (TF) was determined spectrophotometrically $[18,21]$. A sample extract of $20 \mu \mathrm{l}$ was mixed with $60 \mu \mathrm{l}$ ethanol in 96 -well plates. Then, $4 \mu \mathrm{l}$ of $10 \% \mathrm{AlCl}_{3}$ and $4 \mu \mathrm{l}$ of $1 \mathrm{M}$ potassium acetate were added with $112 \mu \mathrm{l}$ deionized water. The solution was incubated in the dark for 45 minutes. The total flavonoid content was measured afterwards using a microplate reader at $415 \mathrm{~nm}$ wavelength. A calibration curve is prepared using a standard solution of quercetin, reported as quercetin equivalents $(\mathrm{QE})$ /gram dry weight extract.

\subsubsection{Determination of Total Polysaccharide Content.} The total polysaccharide (TPS) content was determined with phenol-sulfuric acid method modified from the method of Masuko et al. [22]. In brief, $600 \mu \mathrm{l}$ of extract was mixed with $100 \mu \mathrm{l}$ of $5 \%$ phenol solution. Then, $3 \mathrm{ml}$ of concentrated sulfuric acid was added and left for 10 minutes. Following this step, the solution was shaken well and left for 30 minutes. The TPS content was measured 


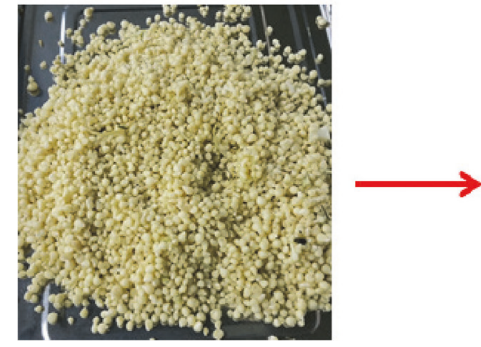

Okra seed

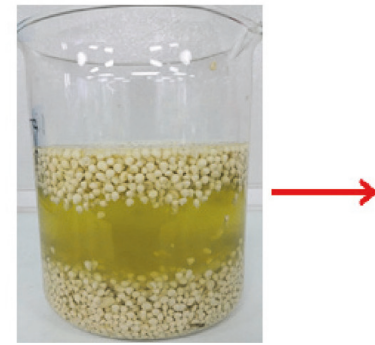

Maceration

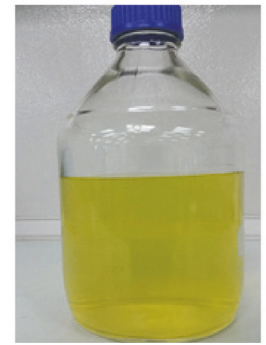

Filtration
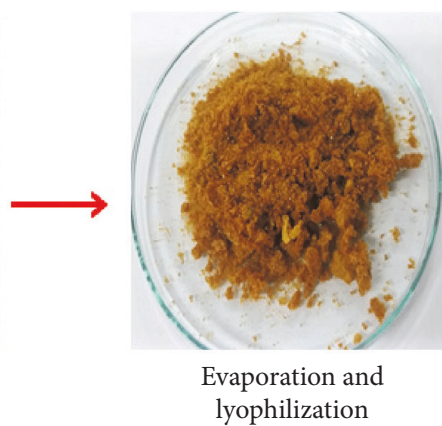

Figure 1: The okra seed extraction process.

using UV-spectrophotometry at $490 \mathrm{~nm}$ wavelength compared with a standard curve obtained from the glucose standard.

2.3.5. Determination of Isoquercitrin. Isoquercitrin quantitative analysis was conducted according to a modified method as described by Seal [23] on a Shimadzu HPLC/DAD using a $250 \mathrm{~mm}$ (Kinetex) column and gradient injection of the mobile phase of $1 \%$ of acetic acid (solvent A): acetonitrile (solvent B) at a flow rate of $0.7 \mathrm{ml} / \mathrm{min}$ and detected at a wavelength $353 \mathrm{~nm}$ ( Table 1).

\subsection{Cell Cultures}

2.4.1. Cell Lines and Cultures. The human breast cancer cell line (MCF-7), human hepatocellular carcinoma (HepG2), and human cervical carcinoma cell line (HeLa) were purchased by our institution from ATCC. The seeding medium for each cell type was as follows: MCF-7 culture in DMEM with $10 \%$ fetal bovine serum containing $1 \%$ antibiotic/ antimycotic and 1\% L-glutamax; HepG2 culture in RPMI1640 medium with $10 \%$ fetal bovine serum containing 1\% antibiotic/antimycotic and 1\% L-glutamax; and HeLa culture in DMEM with $10 \%$ fetal bovine serum containing $1 \%$ antibiotic/antimycotic. Cells were cultured at $37^{\circ} \mathrm{C}$ in $5 \%$ $\mathrm{CO}_{2}$. Media culture was changed every 3 days.

2.4.2. Cytotoxic Assay. The extract was dissolved in complete medium containing 1\% DMSO to clear solution. The cytotoxicity test of cancer cells uses a PrestoBlue assay test method by seeding cells in 96-well plates and incubating for 24 hours. The tests are performed at 24 and 48 hours and measured with a microplate reader at excitation/emission $560 / 590 \mathrm{~nm}$. Each OSE fraction was compared to the crude okra seed extract. The most effective OSE part in the cytotoxicity assay was then further compared to standard isoquercitrin equivalent to isoquercitrin found in the $1,000 \mu \mathrm{g}$ current okra seed extract.

2.4.3. Cell Scratch Assay. Cells plated onto 12-well culture plates in complete medium monolayers, were manually scratched with a yellow pipette tip, followed by washing with PBS. The monolayers were then incubated with complete
TABLe 1: Gradient condition for HPLC analysis of the okra seed extract.

\begin{tabular}{lcc}
\hline Time (min) & Pump A: $1 \%$ acetic acid & Pump B: acetonitrile \\
\hline 0 & 90 & 10 \\
28 & 60 & 40 \\
39 & 40 & 60 \\
50 & 10 & 90 \\
55 & 90 & 10 \\
\hline
\end{tabular}

medium of different concentrations of the okra seed extract at $37^{\circ} \mathrm{C}$ for 24,48 , and 72 hours. The monolayers were photographed at 0 hours and 24 hours after scratching using an inverted microscope (Olympus, Tokyo, Japan) to capture the size of the scratch. The experiments were performed in triplicate for each treatment group.

2.4.4. Cell Invasion Assay. The Boyden chamber migration test was used to study cell invasion. The $8.0 \mu \mathrm{m}$ PET filters 24-well cell culture inserts (Falcon, USA) were coated with Matrigel (Corning) and incubated for $1 \mathrm{~h}$ at $25^{\circ} \mathrm{C}$ to form a thin layer on the filter surface. The complete medium was added to the lower compartment of the chamber. After that, the wells on the upper chamber were seeded with $2 \times 10^{4}$ cell/ well, and okra seed extract was added at different concentrations ranging from 100 to $500 \mu \mathrm{g} / \mathrm{ml}$ in low (1\%) FBS medium. After 48 hours, noninvasive cells were wiped in the upper chamber using a cotton bud; lower and upper chamber were washed three times with PBS ( $\mathrm{pH} 7.4)$ and then fixed with $3 \%$ glutaraldehyde in PBS and stained with $0.5 \%$ crystal violet in PBS. Later, the cells were lysed by using $10 \%$ acetic acid, and the quantity of cells was analyzed by using a microplate reader at a wavelength of $590 \mathrm{~nm}$.

2.4.5. Cell Apoptosis. The cells were cultured in a 6-well cell culture plate at a seeding density of $1 \times 10^{6}$ cells/well incubated for $24 \mathrm{~h}$ at $37^{\circ} \mathrm{C}$ in $5 \% \mathrm{CO}_{2}$ before treating with the extract. The cells were cultured in a 6 -well cell culture plate at a seeding density of $1 \times 10^{6}$ cells/well. After the cells were treated with different doses of the okra seed extract for $48 \mathrm{~h}$, the cells were trypsinized and a single cell suspension was prepared. Then, the cells were stained using Annexin V and 7ADD (Guava Nexin Reagent, Merck Millipore), which were then analyzed by flow cytometry (Guava, Merck Millipore). 
TABLE 2: Phytochemical screening.

\begin{tabular}{lcccc}
\hline & OSE-Hex fraction & OSE-DCM fraction & OSE-EtOH fraction & Okra seed extract \\
\hline $\mathrm{FeCl}_{3}$ test, phenolics & - & - & + & + \\
Shinoda test, flavonoids & - & - & + & + \\
Sodium hydroxide test, flavonoids & - & - & - & + \\
Molisch test, glycosides & - & - & - & + \\
Dragendorff's test, alkaloids & - & - & - \\
Foam test, saponins & - & - & - \\
Gelatin test, tannins & - & & - \\
\hline
\end{tabular}

TABLE 3: Analysis of substance content in the okra seed extract according to partition fractions.

\begin{tabular}{lcccc}
\hline & $\begin{array}{c}\text { OSE-Hex } \\
\text { fraction }\end{array}$ & $\begin{array}{c}\text { OSE-DCM } \\
\text { fraction }\end{array}$ & OSE-EtOH fraction & Okra seed extract \\
\hline Total phenolic (TP) content & - & - & $46.51 \pm 5.61 \mathrm{mg} \mathrm{GAE} / \mathrm{g}$ & $\begin{array}{c}56.66 \pm 1.88 \mathrm{mg} \mathrm{GAE} / \mathrm{g} \\
\text { extract }\end{array}$ \\
$\begin{array}{l}\text { Total flavonoid (TF) content } \\
\text { Total polysaccharide (TPS) }\end{array}$ & - & - & $41.71 \pm 10.88 \mathrm{mg} \mathrm{QE} / \mathrm{g}$ extract & $44.07 \pm 7.03 \mathrm{mg} \mathrm{QE} / \mathrm{g}$ extract \\
content & - & - & $31.74 \pm 1.23 \%$ & $36.73 \pm 2.41 \%$ \\
Isoquercitrin content & - & - & $2.68 \pm 1.92 \%$ & $2.89 \pm 1.64 \%$ \\
\hline
\end{tabular}

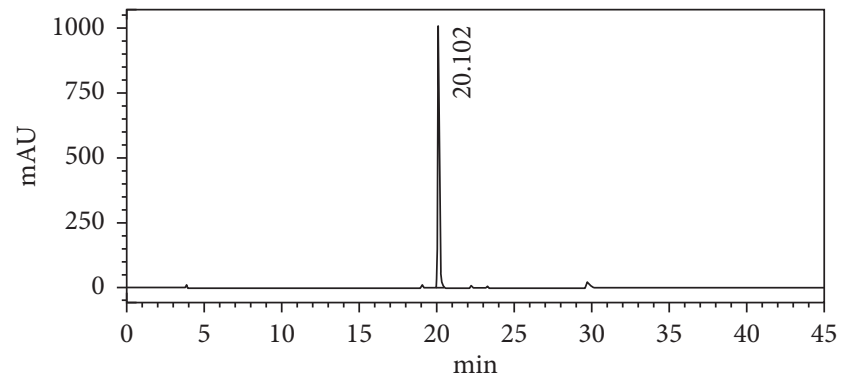

(a)

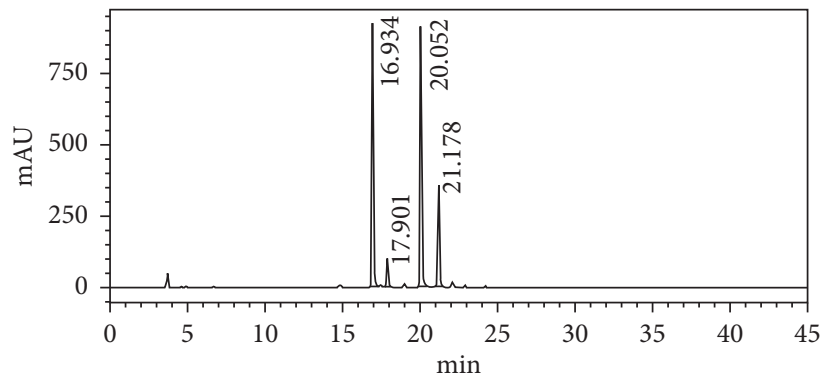

(b)

Figure 2: Chromatogram from HPLC for (a) standard isoquercitrin and (b) okra seed extract.

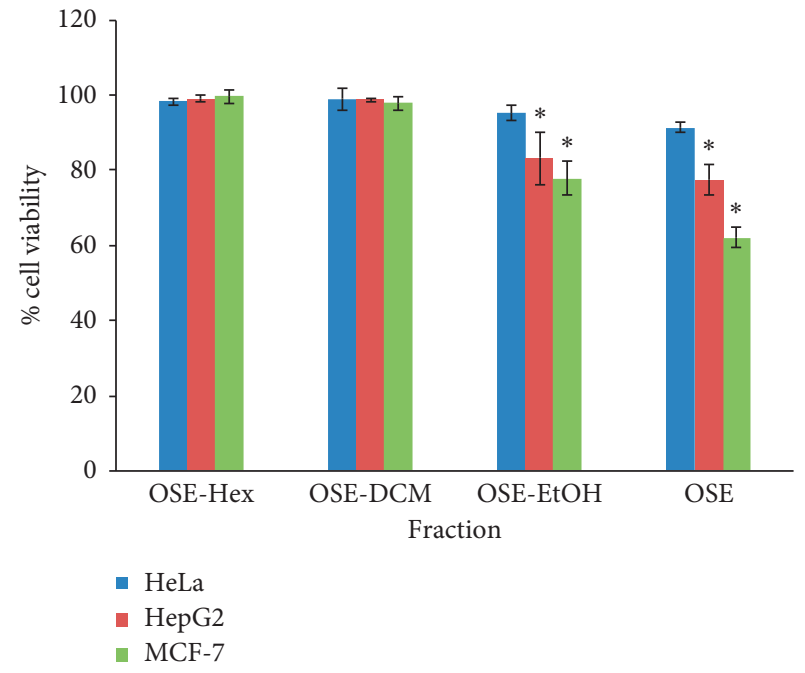

FIGURE 3: Cell viability at 48 hours: comparison between the okra seed extract (OSE) and fractions. Hexane (OSE-Hex), dichloromethane (OSE-DCM), and ethanol (OSE-EtOH). Mean \pm SD $(n=3) .\left(^{*} p<0.05\right.$ versus nontreated controls at $\left.48 \mathrm{hrs}\right)$.

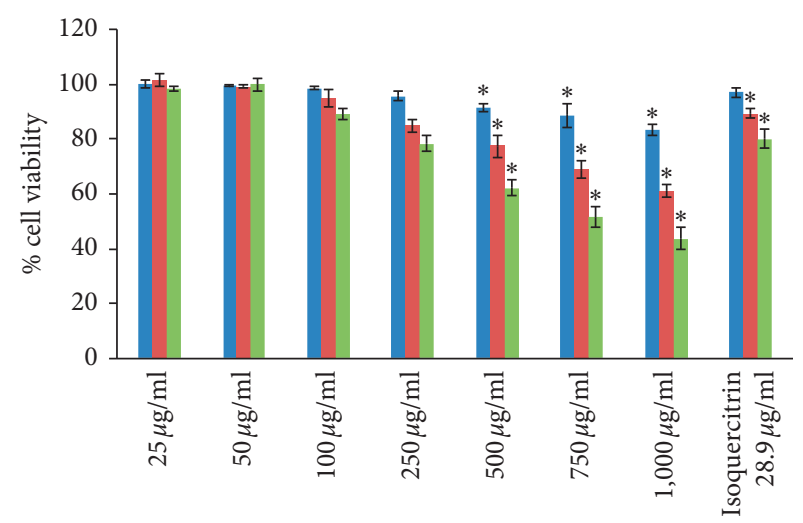

Concentration

$$
\begin{aligned}
& \text { - HeLa } \\
& \text { - HepG2 } \\
& \text { MCF-7 }
\end{aligned}
$$

FIgUre 4: Dose-dependent effect of the okra seed extract (OSE) on cell viability at $48 \mathrm{hrs}$. Mean $\pm \mathrm{SD}(n=3)$. ${ }^{*} p<0.05$ versus nontreated controls. 
TABLE 4: Cell viability percentages (\%) compared to controls at $48 \mathrm{hrs}$.

\begin{tabular}{lccr}
\hline & HeLa $(\%)$ & HepG2 (\%) & MCF-7 (\%) \\
\hline $25 \mu \mathrm{g} / \mathrm{ml}$ & $100.04 \pm 1.23$ & $101.40 \pm 2.27$ & $98.60 \pm 0.84$ \\
$50 \mu \mathrm{g} / \mathrm{ml}$ & $99.38 \pm 0.30$ & $99.19 \pm 0.38$ & $99.90 \pm 2.47$ \\
$100 \mu \mathrm{g} / \mathrm{ml}$ & $98.64 \pm 0.63$ & $94.85 \pm 3.29$ & $89.07 \pm 2.09^{*}$ \\
$250 \mu \mathrm{g} / \mathrm{ml}$ & $95.75 \pm 1.98$ & $84.78 \pm 2.24^{*}$ & $78.35 \pm 3.09^{*}$ \\
$500 \mu \mathrm{g} / \mathrm{ml}$ & $91.40 \pm 1.30^{*}$ & $77.41 \pm 4.11^{*}$ & $62.11 \pm 2.82^{*}$ \\
$750 \mu \mathrm{g} / \mathrm{ml}$ & $88.56 \pm 4.44^{*}$ & $68.72 \pm 3.21^{*}$ & $51.39 \pm 3.78^{*}$ \\
$1,000 \mu \mathrm{g} / \mathrm{ml}$ & $83.38 \pm 1.81^{*}$ & $60.97 \pm 2.26^{*}$ & $43.60 \pm 4.13^{*}$ \\
Isoquercitrin $28.9 \mu \mathrm{g} / \mathrm{ml}$ & $97.10 \pm 1.70$ & $89.38 \pm 1.84^{*}$ & $79.99 \pm 3.43^{*}$ \\
\hline
\end{tabular}

Results are shown as mean $\pm \mathrm{SD}(n=3) .{ }^{*} p<0.05$ versus nontreated controls.

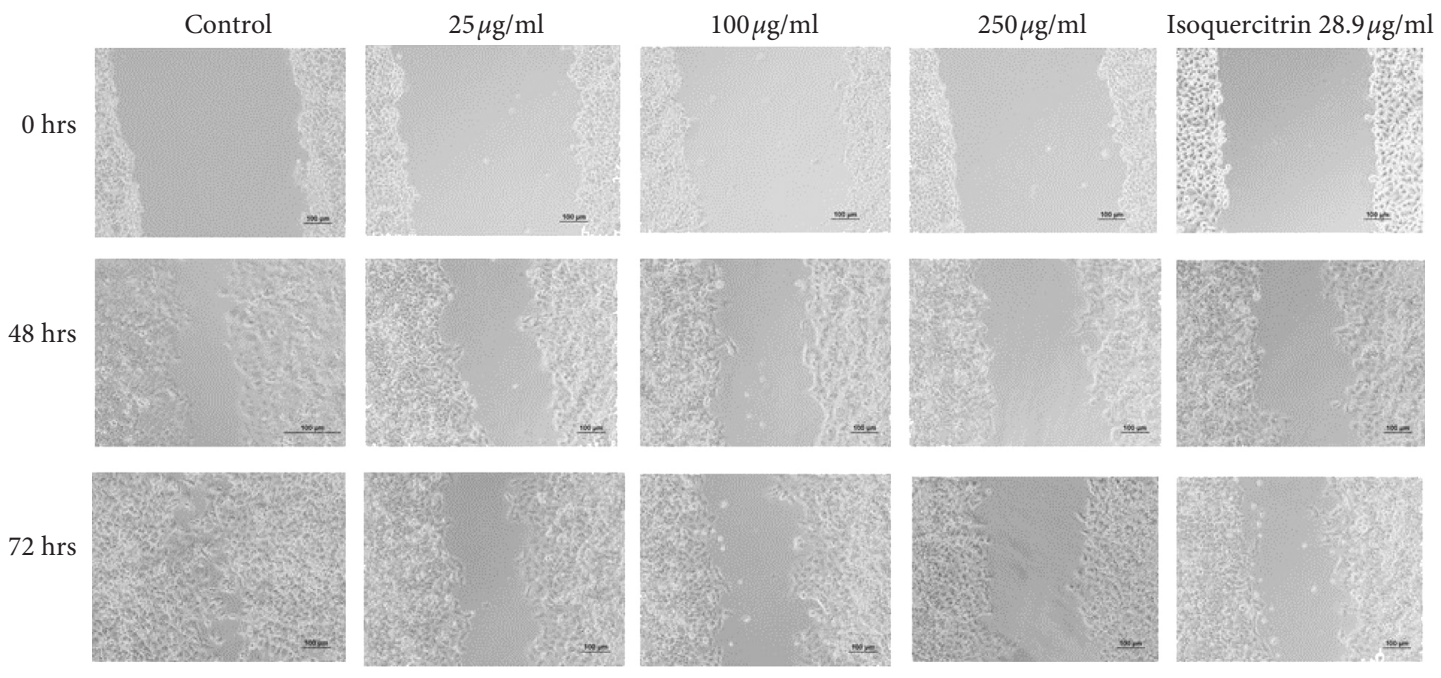

(a)

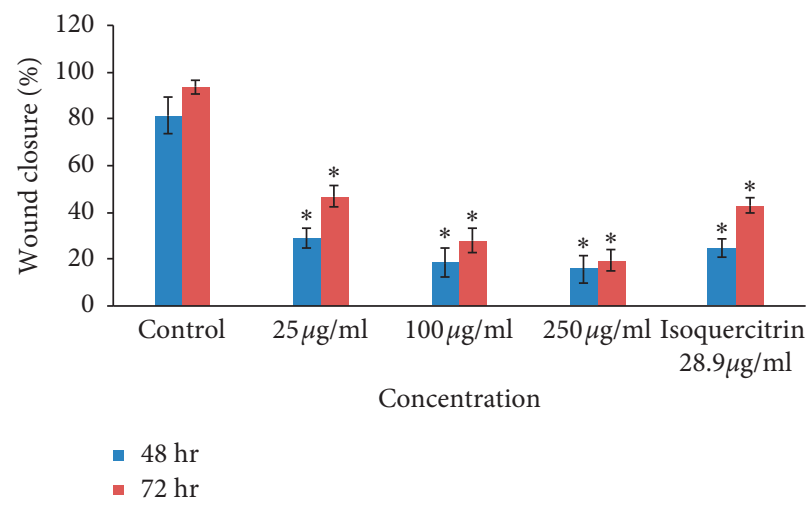

(b)

Figure 5: (a) Cell migration (HeLa). (b) Cell migration (HeLa). Results are shown as mean $\pm \mathrm{SD}(n=3) .{ }^{*} p<0.05$ versus nontreated controls at the same time point.

TABle 5: Percentage wound closure in the cell migration test compared on day 0 .

\begin{tabular}{|c|c|c|c|c|c|c|}
\hline & & Control & $25 \mu \mathrm{g} / \mathrm{ml}$ & $100 \mu \mathrm{g} / \mathrm{ml}$ & $250 \mu \mathrm{g} / \mathrm{ml}$ & Isoquercitrin $28.9 \mu \mathrm{g} / \mathrm{ml}$ \\
\hline \multirow{3}{*}{$48 \mathrm{hr}$} & $\mathrm{HeLa}$ & $81.50 \pm 7.87$ & $28.67 \pm 4.25^{*}$ & $18.44 \pm 6.14^{*}$ & $15.77 \pm 5.98^{*}$ & $24.64 \pm 3.92^{*}$ \\
\hline & HepG2 & $9.77 \pm 1.83$ & $9.71 \pm 4.33$ & $8.35 \pm 1.33$ & $8.71 \pm 1.56$ & $7.75 \pm 0.38$ \\
\hline & MCF-7 & $89.70 \pm 1.43$ & $20.80 \pm 4.86^{*}$ & $14.51 \pm 2.11^{*}$ & $13.98 \pm 2.48^{*}$ & $14.99 \pm 1.69^{*}$ \\
\hline \multirow{3}{*}{$72 \mathrm{hr}$} & $\mathrm{HeLa}$ & $93.73 \pm 2.97^{*}$ & $46.92 \pm 4.60^{*}$ & $27.73 \pm 5.25^{*}$ & $19.48 \pm 4.69^{*}$ & $42.95 \pm 3.36^{*}$ \\
\hline & HepG2 & $30.45 \pm 5.60^{*}$ & $16.97 \pm 1.14^{*}$ & $15.05 \pm 1.67^{*}$ & $15.51 \pm 2.18^{*}$ & $16.30 \pm 1.75^{*}$ \\
\hline & MCF-7 & $98.14 \pm 0.95^{*}$ & $53.69 \pm 4.25^{*}$ & $22.38 \pm 2.91^{*}$ & $16.74 \pm 1.18^{*}$ & $20.25 \pm 0.93^{*}$ \\
\hline
\end{tabular}

Results are shown as mean \pm SD $(n=3) .{ }^{*} p<0.05$ versus nontreated controls. 


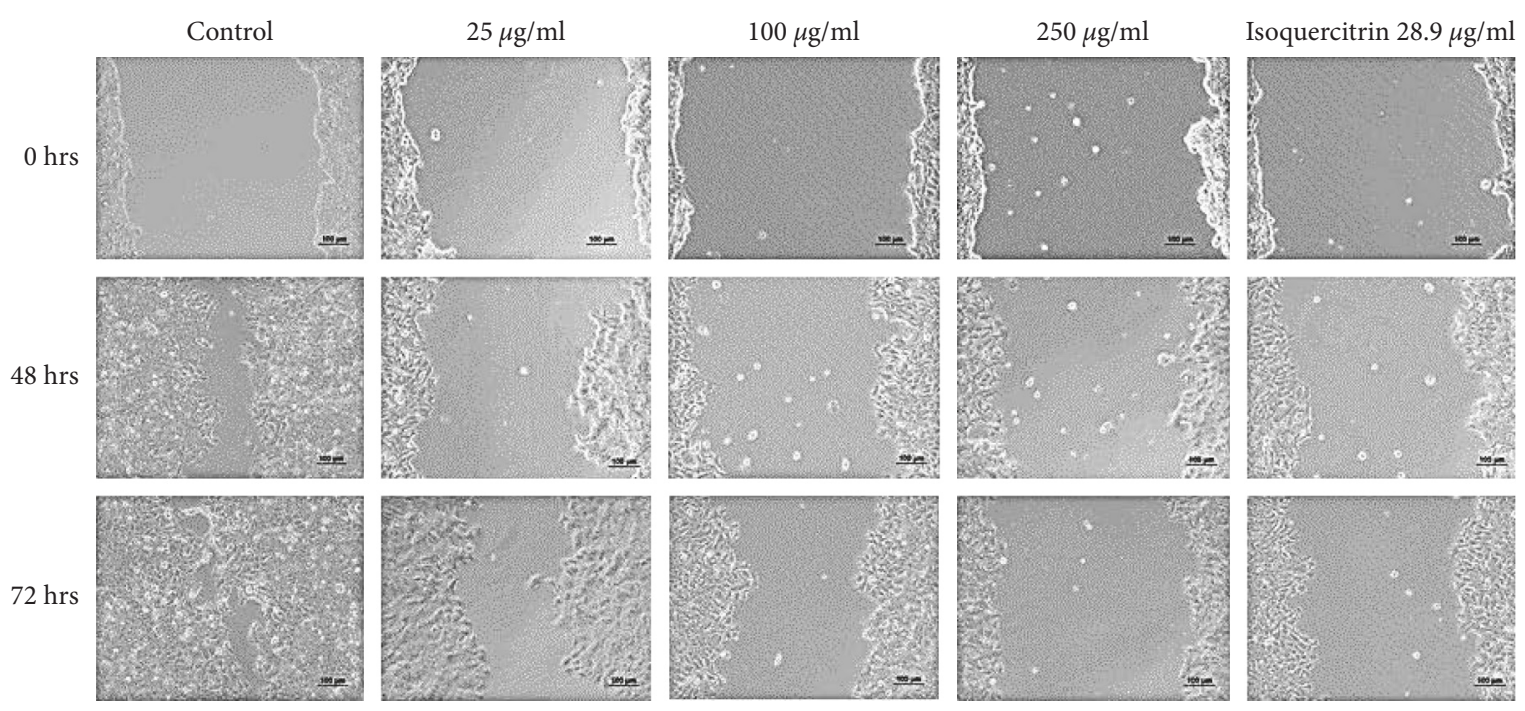

(a)

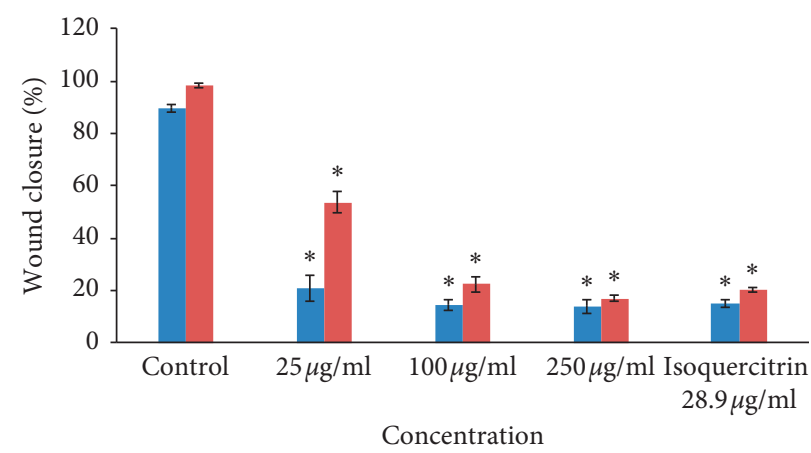

- $48 \mathrm{hr}$

- $72 \mathrm{hr}$

(b)

Figure 6: (a) Cell migration (MCF-7). (b) Cell migration (MCF-7). Results are shown as mean $\pm \mathrm{SD}(n=3) .{ }^{*} p<0.05$ versus nontreated controls at the same time point.

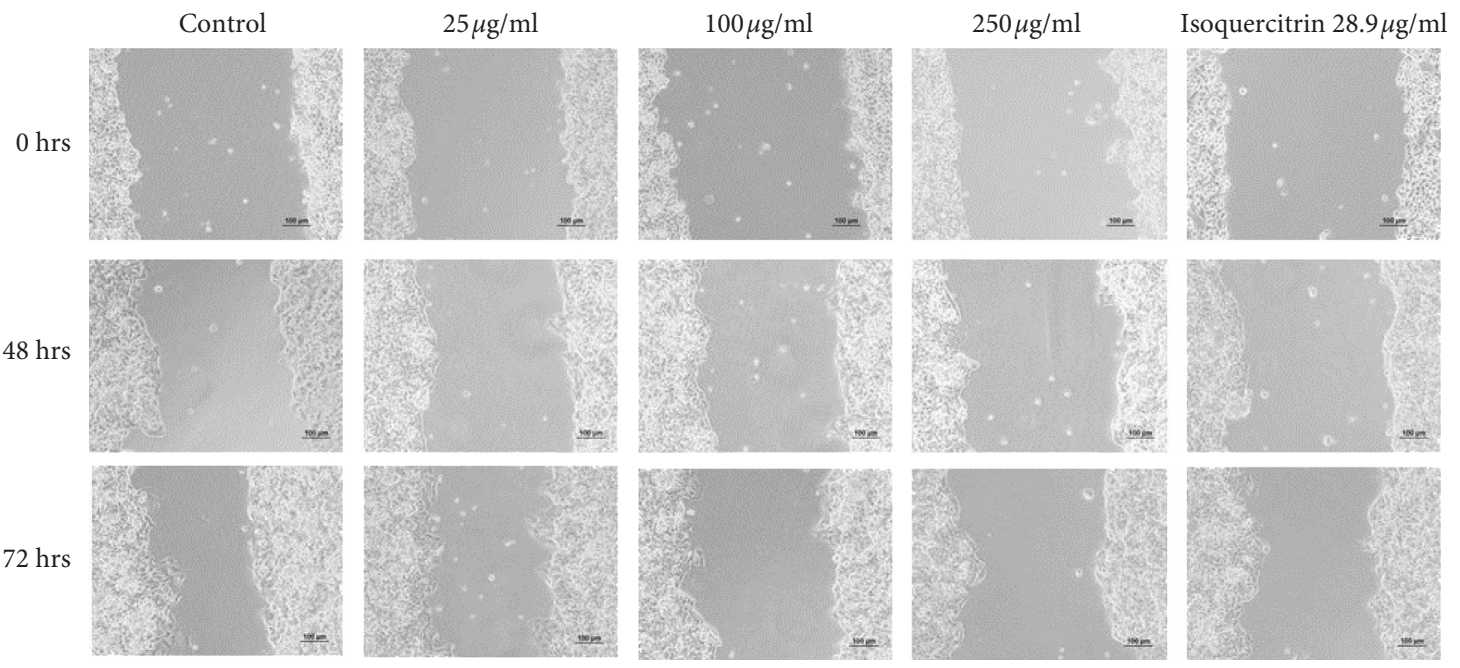

(a)

FIGURE 7: Continued. 


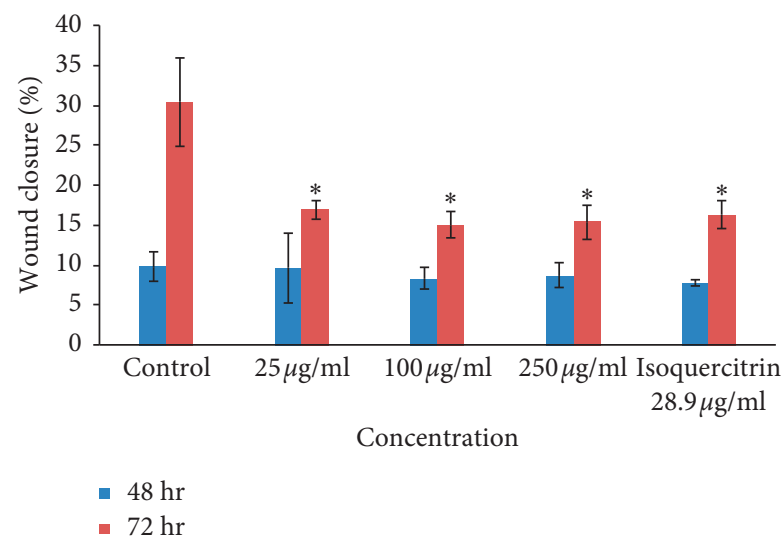

(b)

Figure 7: (a) Cell migration (HepG2). (b) Cell migration (HepG2). Results are shown as mean $\pm \mathrm{SD}(n=3) .{ }^{*} p<0.05$ versus nontreated controls at the same time point.
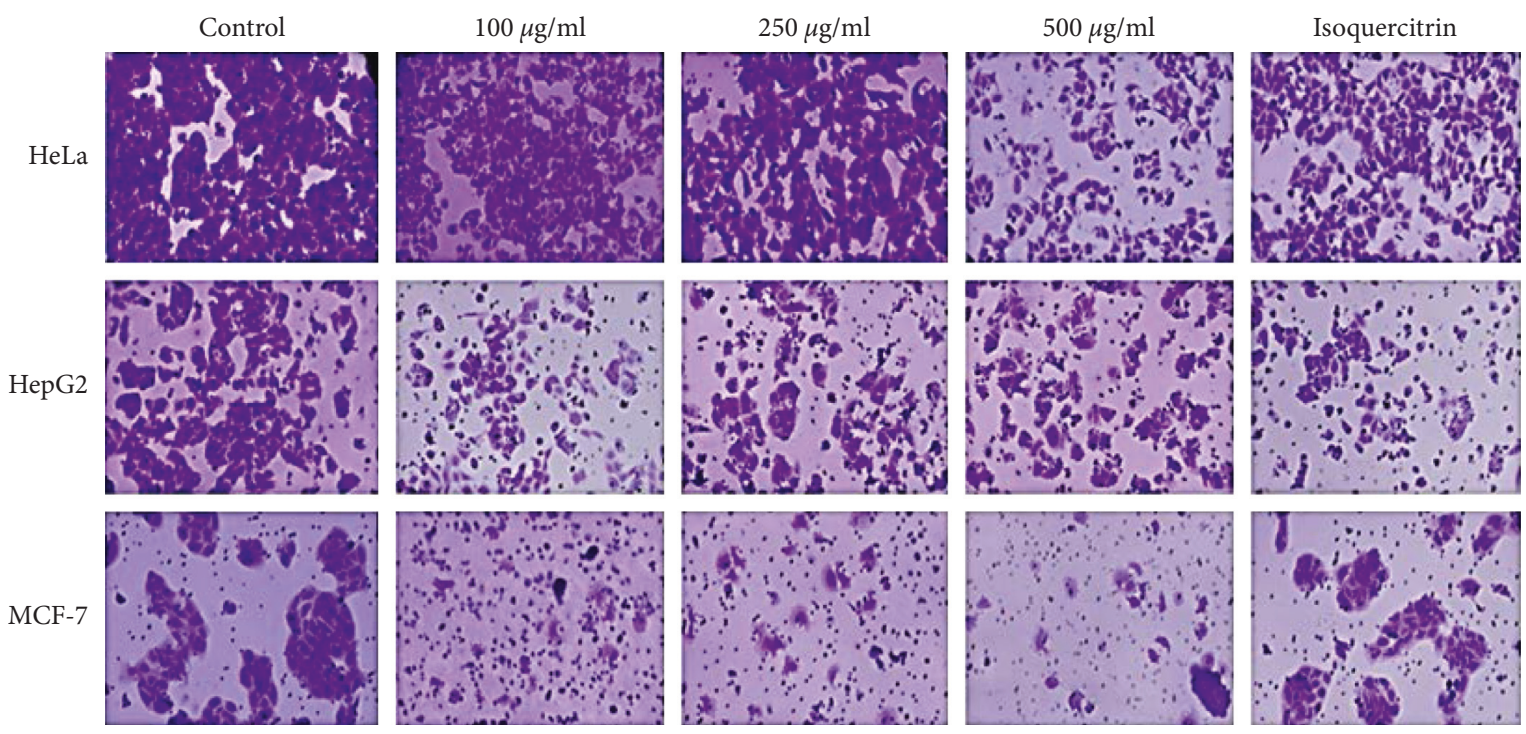

(a)

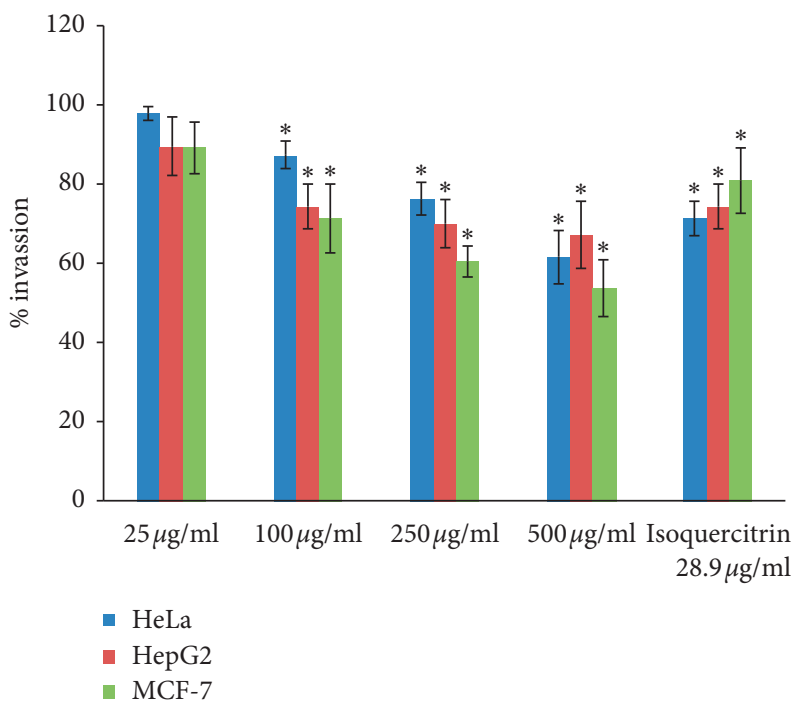

(b)

Figure 8: (a) Cell invasion inhibition. (b) Cell invasion inhibition. Results are shown as mean $\pm \operatorname{SD}(n=3) .{ }^{*} p<0.05$ versus nontreated controls. 
TABle 6: Percentage cell invasion compared with controls.

\begin{tabular}{lccc}
\hline & HeLa & HepG2 & MCF-7 \\
\hline $25 \mu \mathrm{g} / \mathrm{ml}$ & $98.01 \pm 1.82$ & $89.67 \pm 7.30$ & $89.25 \pm 6.75$ \\
$100 \mu \mathrm{g} / \mathrm{ml}$ & $87.34 \pm 3.56^{*}$ & $74.32 \pm 5.64^{*}$ & $71.46 \pm 8.79^{*}$ \\
$250 \mu \mathrm{g} / \mathrm{ml}$ & $76.25 \pm 4.12^{*}$ & $70.12 \pm 6.15^{*}$ & $60.63 \pm 3.83^{*}$ \\
$500 \mu \mathrm{g} / \mathrm{ml}$ & $61.73 \pm 6.87^{*}$ & $67.35 \pm 8.47^{*}$ & $53.71 \pm 7.14^{*}$ \\
Isoquercitrin & $71.43 \pm 4.24^{*}$ & $74.41 \pm 5.72^{*}$ & $81.06 \pm 8.27^{*}$ \\
$28.9 \mu \mathrm{g} / \mathrm{ml}$ & & & \\
\hline
\end{tabular}

Results are shown as mean $\pm \mathrm{SD}(n=3) .{ }^{*} p<0.05$ versus nontreated controls.

2.4.6. Antiangiogenesis. Cancer cells were seeded on 12-well plates and incubated for $24 \mathrm{~h}$ at $37^{\circ} \mathrm{C}$ in $5 \% \mathrm{CO}_{2}$. After that, the old medium was washed, and okra seed extract was added at different concentrations ranging from 25 to $1,000 \mu \mathrm{g} / \mathrm{ml}$ in medium and incubated for 24 and 48 hours. After that, the supernatant was collected and centrifuged to analyze the quantity of vascular endothelial growth factor (VEGF) by using a sandwich ELISA (VEGF ELISA kit, Abcam). The obtained supernatant was placed in a 96-well plate kit according to the company protocol and analyzed for VEGF by using the microplate reader at a wavelength of $450 \mathrm{~nm}$.

\subsection{Preparation and Characterization of Okra Seed Extract Loaded in Polymeric Micelles}

2.5.1. Preparation of OSE-Loaded Micelles. OSE-loaded micelles were prepared by the thin-film hydration method. In brief, $50 \mathrm{mg}$ of okra seed extract and poloxamer 407 were dissolved in ethanol in a round bottom flask. Each formulation used different concentrations of poloxamer 407, ranging between 50 and $1,000 \mathrm{mg}$ of poloxamer 407 . Then, the solvent was made to evaporate to a solid film in a solvent evaporator at $50^{\circ} \mathrm{C}$. After that, the dried film was dehydrated with $10 \mathrm{ml}$ deionized water and was sonicated for $15 \mathrm{~min}$ utes. The solution was filtrated by using a $0.45 \mu \mathrm{m}$ syringe filter.

2.5.2. Characterization of OSE-Loaded Micelles. Particle size and entrapment efficiency were studied. Diameter, polydispersity index (PDI), and zeta potential of micelles were determined by dynamic light scattering using a Malvern Nano ZS (Malvern Instruments Ltd., Worcestershire, UK). Entrapment efficacy was evaluated by disrupting the micelles in acetonitrile (Merck Millipore). The okra seed extract was quantified by UV-visible spectrophotometry at $353 \mathrm{~nm}$.

\subsubsection{Anticancer Activity of OSE-Loaded Micelles.} Optimum dose (for micellar formation) OSE-loaded micelles were tested for cancer cell cytotoxicity using the PrestoBlue assay method as described in Section 2.4.2. OSEloaded micelles and blank micelles were compared to each other after dilution with cell culture medium to a concentration comparable with okra seed extracts of $500 \mu \mathrm{g} / \mathrm{ml}$.

2.6. Statistical Analysis. Data were expressed as mean\pm standard deviation (SD). The statistical differences between the means were determined using one-way ANOVA. The differences were considered significant when the probability value obtained was found to be less than $0.05(p<0.05)$.

\section{Results and Discussion}

From the results of the phytochemical tests, it was deduced that the okra seed extract contained flavonoid glycosides, positive for the Molisch test, as well as for the $\mathrm{FeCl}_{3}$, Shinoda, and sodium hydroxide tests (Table 2).

The quantitative analysis results were consistent with the results of phytochemical screening, meaning that the substances found in the okra seed extract were as in the group of flavonoid glycosides. The total phenolic (TP) and total flavonoid (TF) contents were found highest in okra seed extract (Table 3).

We observed that the major constituents were detected in the ethanol layer, in concentrations close to the okra seed extract albeit lower. In addition, the TPS content, an important part of flavonoid glycoside constituent, was relatively high at $36.73 \%$ in the okra seed extract. The HPLC chromatogram showed four semipolar peaks consistent with isoquercitrin and three other phenolic compounds appearing in the early stages that were not present when partitioned using hexane and dichloromethane (Figure 2).

3.1. Cytotoxicity. When the cytotoxic effect of the OSE and its various fractions was tested on the three cancer cell lines, we observed no effects of the hexane (OSE-Hex) and dichloromethane (OSE-DCM) fractions compared to the controls. When the ethanol fraction (OSE-EtOH) and the okra seed extract were applied, the latter had a more significant cytotoxic effect, possibly due to the synergy of various substances in preventing cancer growth (Figure 3) [24-26]. In the present study, the onset of the okra seed extract's cytotoxic effect appeared at 48 hours without any visible effects at 24 hours (data not shown), indicating a possibly chronically toxic effect.

A dose-dependent effect of the okra seed extract was noted, commencing already at the $100 \mu \mathrm{g} / \mathrm{ml}$ dose. The cytotoxic effects were highest on the growth of the MCF-7 cell lines, followed by the HepG2 (Figure 4). The effect was minimal for the HeLa cell line indicating resistance to the extract as reported by Jarial et al. [27] for both quercetin and rutin $[24,25]$. Interestingly, the effects of standard isoquercitrin were inferior to the okra seed extract. In the MCF-7 cell line, an OSE concentration of $250 \mu \mathrm{g} / \mathrm{ml}$, containing not more than $7.2 \mu \mathrm{g} / \mathrm{ml}$ of isoquercitrin, was as cytotoxic as the equivalent of $28.9 \mu \mathrm{g} / \mathrm{ml}$ pure isoquercitrin. When an OSE concentration of $1000 \mu \mathrm{g} / \mathrm{ml}$ containing the equivalent of $28.9 \mu \mathrm{g} / \mathrm{ml}$ pure isoquercitrin was used, we observed a potentiated cytotoxic effect for the OSE resulting in $43.6 \%$ MCF-7 cell viability compared to $79.9 \%$ for pure isoquercitrin (Table 4). We hypothesize that the remaining three unknown flavonoids observed in the HPLC chromatogram (Figure 2) separately or in synergy with isoquercitrin are responsible for the OSE's observed potentiated cytotoxic effects. 


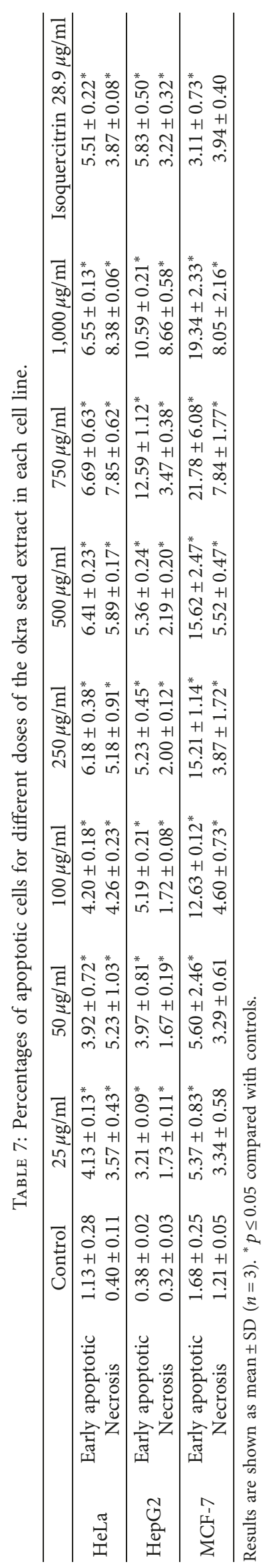


TABLE 8: VEGF content analysis (pg/ml).

\begin{tabular}{lcccccc}
\hline & & Control & $100 \mu \mathrm{g} / \mathrm{ml}$ & $250 \mu \mathrm{g} / \mathrm{ml}$ & $500 \mu \mathrm{g} / \mathrm{ml}$ & \multicolumn{2}{c}{ Isoquercitrin $28.9 \mu \mathrm{g} / \mathrm{ml}$} \\
\hline \multirow{2}{*}{ HeLa } & 24 hours & $125.96 \pm 7.14$ & $128.19 \pm 51.24$ & $113.00 \pm 17.46$ & $92.26 \pm 14.50$ & $121.76 \pm 23.91$ \\
& 48 hours & $240.41 \pm 14.67$ & $184.48 \pm 7.14^{*}$ & $141.15 \pm 2.79^{*}$ & $141.89 \pm 4.84^{*}$ & $168.26 \pm 14.18^{*}$ \\
\hline \multirow{2}{*}{ HepG2 } & 24 hours & $253.74 \pm 6.12$ & $233.74 \pm 5.48$ & $178.56 \pm 10.72^{*}$ & $158.56 \pm 27.31^{*}$ & $193.61 \pm 19.04^{*}$ \\
& 48 hours & $543.37 \pm 23.74$ & $278.93 \pm 3.91^{*}$ & $267.81 \pm 9.45^{*}$ & $190.41 \pm 8.98^{*}$ & $263.24 \pm 8.16^{*}$ \\
\hline \multirow{2}{*}{ MCF-7 } & 24 hours & $205.96 \pm 21.92$ & $193.74 \pm 57.42$ & $157.44 \pm 46.20$ & $129.30 \pm 9.86$ & $164.92 \pm 21.83$ \\
& 48 hours & $302.26 \pm 12.64$ & $225.89 \pm 15.75^{*}$ & $145.22 \pm 11.76^{*}$ & $137.81 \pm 11.56^{*}$ & $178.48 \pm 15.62^{*}$ \\
\hline
\end{tabular}

Results are shown as mean \pm SD $(n=3) .{ }^{*} p \leq 0.05$ compared to controls.

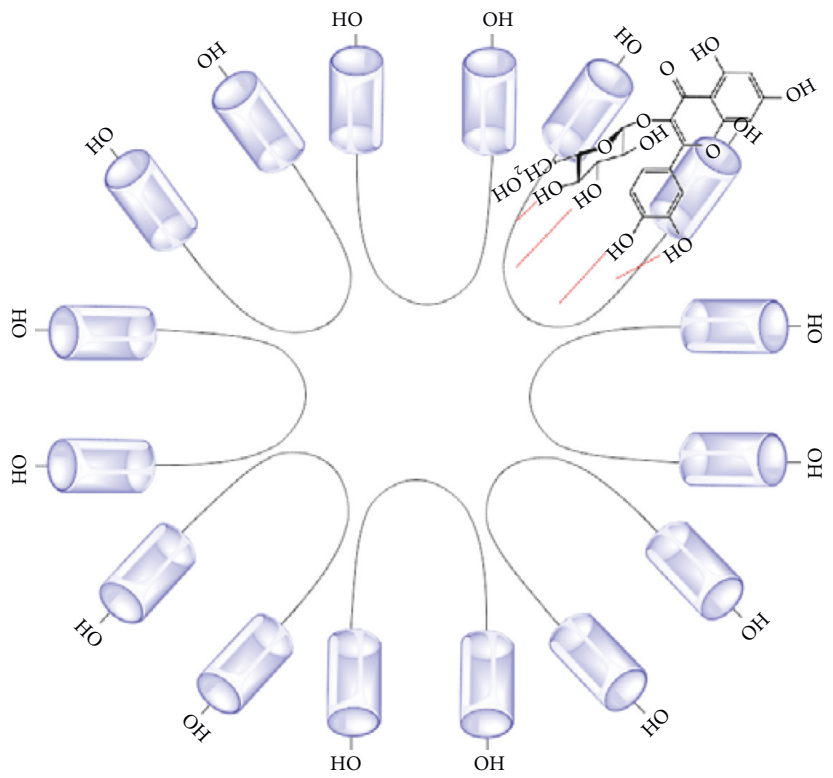<smiles></smiles>

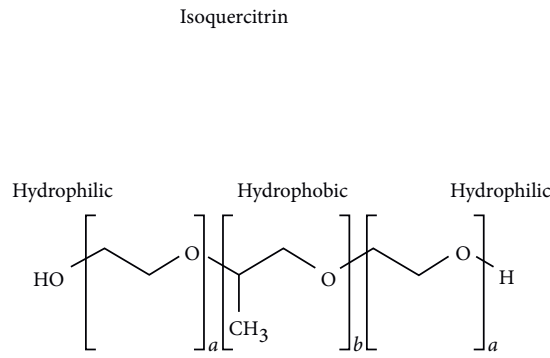

FIgUre 9: Possible location of isoquercitrin in micelles.

TABLE 9: Physical properties of okra seed extract polymeric micelle formation.

\begin{tabular}{|c|c|c|c|c|}
\hline Ratio (extract: poloxamer) & Size $(\mathrm{nm})$ & PDI & Zeta potential & $\% \mathrm{EE}$ \\
\hline $50: 50$ & $391.63 \pm 43.52$ & $0.36 \pm 0.04$ & $-9.54 \pm 3.42$ & $79.82 \pm 0.29$ \\
\hline $50: 100$ & $404.03 \pm 36.46$ & $0.42 \pm 0.08$ & $-15.00 \pm 5.10$ & $83.57 \pm 0.75$ \\
\hline $50: 200$ & $442.72 \pm 72.43$ & $0.44 \pm 0.05$ & $-15.27 \pm 3.88$ & $86.56 \pm 0.54$ \\
\hline $50: 500$ & $190.23 \pm 46.96$ & $0.34 \pm 0.05$ & $-14.70 \pm 4.88$ & $93.43 \pm 2.45$ \\
\hline $50: 1,000$ & $167.57 \pm 110.58$ & $0.99 \pm 0.01$ & $-16.02 \pm 6.72$ & $86.88 \pm 1.93$ \\
\hline
\end{tabular}

3.2. Cell Migration and Cell Invasion. The okra seed extract displayed inhibition of migration in two of the three cancer cell lines (MCF-7 and HeLa) in the cell scratch assay. The OSE extract's effects on migration inhibition in the HeLa cell line (Figures 5(a) and 5(b); Table 5) was already evident at $25 \mu \mathrm{g} / \mathrm{ml}$ concentrations with a wound closure of $28.67 \pm 4.25 \%$ compared to controls which showed a wound closure of up to $81.50 \pm 7.87 \%$. Similar results were noted in the MCF-7 cell line beginning at OSE concentrations of $100 \mu \mathrm{g} / \mathrm{ml}$ (Figures 6(a) and 6(b); Table 5). Pure isoquercitrin showed similar albeit weaker effects compared to the crude extract. The HepG2 cells grow and divide in groups in overlapping layers; hence, the split and side of the heel appears less noticeable (Figures 7(a) and 7(b); Table 5) when the HepG2 cells were scratched while the MCF-7 prefers to divide horizontally into a monolayer rather than overlapping.
The Boyden chamber migration test revealed dose-dependent effects on all 3 cell lines and all 3 doses of the okra seed extract, already appearing at the lowest dose tested (Figures 8(a) and 8(b); Table 6). At all doses, the MCF-7 cell line exhibited the highest level of invasion inhibition followed by the HepG2 cells and HeLa cells, respectively. Isoquercitrin alone used as control resulted in similar effects, in the inverse order of effect on the three cell lines. Our results are in agreement with the findings of Dai et al. [28] and Zhang et al. [29].

3.3. Cell Apoptosis. Earlier in the results section of current study, we evaluated the okra seed extract's cytotoxic effect and reported that such effects were dose and time-dependent and highest for the MCF-7 cell lines, followed by the HepG2 while the effect was minimal for the HeLa cell line indicating 


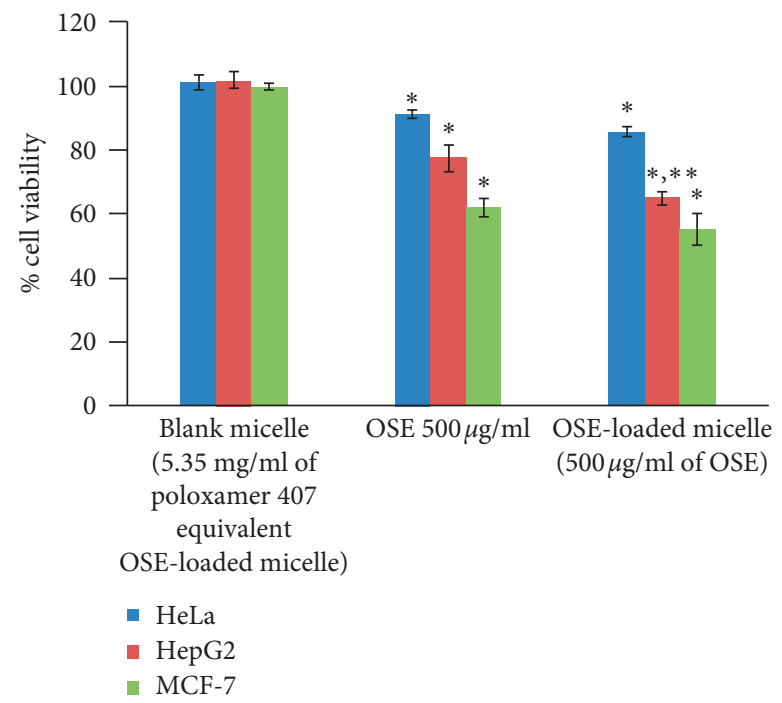

Figure 10: Cytotoxic activity of okra seed extract-loaded polymeric micelles. Results are shown as mean \pm SD $(n=3)$. ${ }^{*} p<0.05$ versus nontreated controls and ${ }^{*} p<0.05$ versus OSE group.

TABLe 10: Cytotoxic activity of okra seed extract-loaded polymeric micelles.

\begin{tabular}{lccc}
\hline & Blank micelle & OSE $500 \mu \mathrm{g} / \mathrm{ml}$ & OSE-loaded micelle $(500 \mu \mathrm{g} / \mathrm{ml}$ of OSE) \\
\hline HeLa & $101.27 \pm 2.42$ & $91.40 \pm 1.30^{*}$ & $85.57 \pm 1.55^{*}$ \\
HepG2 & $101.80 \pm 2.52$ & $77.41 \pm 4.11^{*}$ & $65.01 \pm 2.18^{*},,^{* *}$ \\
MCF-7 & $99.72 \pm 1.03$ & $62.15 \pm 2.82^{*}$ & $55.24 \pm 4.88^{*}$ \\
\hline
\end{tabular}

Results are shown as mean $\pm \mathrm{SD}(n=3) .{ }^{*} p<0.05$ versus nontreated controls.

resistance to the extract. The incubation with the extract showed a significant effect on the apoptosis assay. Table 7 shows that cells treated with $25,50,100,250,500,750$, and $1,000 \mu \mathrm{g} / \mathrm{mL}$ okra seed extract for $48 \mathrm{~h}$ resulted in a significant increase in the percentage of apoptotic cells (early and late apoptosis) in a manner consistent with its cytotoxic effects. Thus, the MCF-7 cell line was the most responsive to induction of early and late apoptosis in a dose-dependent manner already at low doses, but slightly declined at the highest dose. Similar albeit weaker effects were noted for the HeLa and HepG2 cell lines. The results are consistent with numerous studies that found that substances in the flavonoid group may induce apoptosis of cancer cells [30-32]. In addition, different types of flavonoids may exhibit differential effects in a multitude of cancer cells, such as flavonoids extracted from propolis may induce more apoptosis in breast cancer than in colon cancer [33]. The chemical structure of different flavonoids may affect their antiradical activity, and thus induce differential effects on cancer cell inhibition [34].

3.4. Antiangiogenesis. In the present study, we observed that the OSE exerted its VEGF inhibition in a dose-depended manner on all 3 cell lines both at 24 and 48 hours, but this effect was only significant at 48 hours in accordance with previous reports on flavonoids and isoquercitrin (Table 8) $[35,36]$.

3.5. Polymeric Micelles. Poloxamer 407 is a nonionic triblock copolymer. The structure consists of 3 parts; the flanks are made by two hydrophilic chains of polyoxyethylene and a middle hydrophobic chain of polyoxypropylene. The structure is bent into the U-shape when poloxamer 407 forms the micelles, with the hydrophobic part facing inwards in the micelle and the hydrophilic part facing outwards (Figure 9). Our working hypothesis on the micelle interface is that the hydroxyl group of the flavonoid glycoside loaded from our extract will form a hydrogen bond with the poloxamer's oxygen atom causing it to be entrapped into the micelle as presented by Chat et al. [37].

The okra seed extract was loaded to the polymeric micelles using poloxamer 407 as the micellar. The optimum dose for poloxamer 407 was shown to be 50:500 as other ratios resulted in either small or inefficient micelles (Table 9). When the poloxamer 407 concentration increased, the polydispersity index (PDI) increased too, causing densely packed micelle formation in various forms and shapes and inadequate entrapment efficacy.

The blank polymeric micelles did not exert any cytotoxic effect to any of the cancer cell lines. When okra seed extract was added to the polymeric micelles, water solubility increased and cytotoxicity was enhanced (Figure 10, Table 10). The increased water solubility might increase the extract's penetration rate into the cells, thereby inhibiting their growth. However, the polymeric micelle delivery system's cytotoxicity increase was only significant in the HepG2 cell line with little change in the MCF-7 and HeLa lines (Figure 10, Table 10). Previous studies reported that efflux pumps and $p$-glycoproteins are localized on the cell membrane of breast cancer cells and help transport 
substances in and out of the cells, potentially rending them resistant to chemotherapy [38]. Similar reports have been published on cervical cancer $[39,40]$. The polymeric micelle delivery system used in the present study was an initial prototype aimed to increase the solubility of the okra seed extract. Future studies are in order to devise more specific drug-targeting system to cancer cells, such as conjugation to folic acid [41, 42].

\section{Conclusion}

In the present study, we successfully confirmed the presence of flavonoid compounds in the okra plant seed extract and evaluated the extract's effect on the three cancer cell lines delivered in its native form as well as in the form of polymeric micelles. The direct delivery of okra seed extract had the highest cytotoxic effect on the breast cancer cell line (MCF-7), followed by the hepatocellular carcinoma (HepG2) and cervical carcinoma (HeLa) cell lines in that order, while its delivery in a polymeric micelle further increased this effect only in the HepG2 cell line. The okra seed extract's effect demonstrated a dose and time-dependent cell proliferation and migration inhibition plausibly due to VEGF production inhibition, leading to apoptosis and cell death. The observed OSE effects on cancer cell lines may stem from the four flavonoid compounds in the current study, one of which was isoquercitrin. However, in view of the latter compound's isolated effects being inferior to those observed by the OSE, we hypothesize that either isoquercitrin requires the biological synergy of any one or all of the observed flavonoids or any of the three in isolation or all in concert are responsible. Further studies are required to elucidate the nature of the three unknown compounds. Furthermore, as we encountered significant problems in dissolving the okra seed extract and creating the polymeric micelles, further studies are needed to devise a clinically beneficial delivery and targeting system.

\section{Data Availability}

The raw data used to support the findings of this study are currently under embargo while the research findings are commercialized. Requests for data, 12 months after publication of this article, will be considered by the corresponding author.

\section{Conflicts of Interest}

The authors declare that they have no conflicts of interest.

\section{Acknowledgments}

The authors wish to thank the Department of Pharmaceutics and Industrial Pharmacy, Faculty of Pharmaceutical Sciences, Chulalongkorn University, for providing the necessary facilities and instruments for the duration of the study.

\section{References}

[1] S. Khazaei, H. Salehiniya, and A. Mohammadian-Hafshejani, "Some facts about cancer in the world using registered cancer in 2012," Iranian Journal of Public Health, vol. 44, no. 11, pp. 1559-1560, 2015.

[2] C. S. Dela Cruz, L. T. Tanoue, and R. A. Matthay, "Lung cancer: epidemiology, etiology, and prevention," Clinics in Chest Medicine, vol. 32, no. 4, pp. 605-644, 2011.

[3] N. Roswall and E. Weiderpass, "Alcohol as a risk factor for cancer: existing evidence in a global perspective," Journal of Preventive Medicine and Public Health, vol. 48, no. 1, pp. 1-9, 2015.

[4] F. Xia, Y. Zhong, M. Li et al., "Antioxidant and anti-fatigue constituents of okra," Nutrients, vol. 7, no. 10, pp. 8846-8858, 2015.

[5] A. M. Esan, K. Masisi, F. A. Dada, and C. O. Olaiya, "Comparative effects of indole acetic acid and salicylic acid on oxidative stress marker and antioxidant potential of okra (Abelmoschus esculentus) fruit under salinity stress," Scientia Horticulturae, vol. 216, pp. 278-283, 2017.

[6] J. Gates, "Ethnomedicinal, phytochemical and pharmacological profile of genus Abelmoschus," Phytopharmacology, vol. 4, no. 3, pp. 648-663, 2013.

[7] K. Valentová, J. Vrba, M. Bancířová, J. Ulrichová, and V. Křen, "Isoquercitrin: pharmacology, toxicology, and metabolism," Food and Chemical Toxicology, vol. 68, pp. 267-282, 2014.

[8] F. Chen, X. Chen, D. Yang et al., "Isoquercitrin inhibits bladder cancer progression in vivo and in vitro by regulating the PI3K/Akt and PKC signaling pathways," Oncology Reports, vol. 36, no. 1, pp. 165-172, 20161.

[9] Q. Chen, P. Li, P. Li, Y. Xu, Y. Li, and B. Tang, "Isoquercitrin inhibits the progression of pancreatic cancer in vivo and in vitro by regulating opioid receptors and the mitogen-activated protein kinase signalling pathway," Oncology Reports, vol. 33, no. 2, pp. $840-848,2015$.

[10] N. G. Amado, D. Predes, B. F. Fonseca et al., "Isoquercitrin suppresses colon cancer cell growthin vitroby targeting the Wnt/ $\beta$-catenin signaling pathway," Journal of Biological Chemistry, vol. 289, no. 51, pp. 35456-35467, 2014.

[11] W. Xu, P. Ling, and T. Zhang, "Polymeric micelles, a promising drug delivery system to enhance bioavailability of poorly water-soluble drugs," Journal of Drug Delivery, vol. 2013, Article ID 340315, 15 pages, 2013.

[12] H. Chen, C. Khemtong, X. Yang, X. Chang, and J. Gao, "Nanonization strategies for poorly water-soluble drugs," Drug Discovery Today, vol. 16, no. 7-8, pp. 354-360, 2011.

[13] Y. Lu and K. Park, "Polymeric micelles and alternative nanonized delivery vehicles for poorly soluble drugs," International Journal of Pharmaceutics, vol. 453, no. 1, pp. 198-214, 2013.

[14] B. Thapa, P. Kumar, H. Zeng, and R. Narain, "Asialoglycoprotein receptor-mediated gene delivery to hepatocytes using galactosylated polymers," Biomacromolecules, vol. 16, no. 9, pp. 3008-3020, 2015.

[15] F. O. Adetuyi and T. A. Ibrahim, "Effect of fermentation time on the phenolic, flavonoid and vitamin $\mathrm{C}$ contents and antioxidant activities of okra (Abelmoschus esculentus) seeds," Nigerian Food Journal, vol. 32, no. 2, pp. 128-137, 2014.

[16] M. Q. Samejo, A. Sumbul, S. Shah, S. B. Memon, and S. Chundrigar, "Phytochemical screening of Tamarix dioica Roxb. ex Roch," Journal of Pharmacy Research, vol. 7, no. 2, pp. 181-183, 2013. 
[17] R. María, M. Shirley, C. Xavier et al., "Preliminary phytochemical screening, total phenolic content and antibacterial activity of thirteen native species from Guayas province Ecuador," Journal of King Saud University-Science, vol. 30, no. 4, pp. 500-505, 2018.

[18] M. Stankovic, "Total phenolic content, flavonoid concentration and antioxidant activity of Marrubium peregrinum L. extracts," Kragujevac Journal of Science, vol. 33, pp. 63-72, 2011.

[19] L. Méndez-Lagunas, J. Rodríguez-Ramírez, M. Cruz-Gracida, S. Sandoval-Torres, and G. Barriada-Bernal, "Convective drying kinetics of strawberry (Fragaria ananassa): effects on antioxidant activity, anthocyanins and total phenolic content," Food Chemistry, vol. 230, pp. 174-181, 2017.

[20] M. D. Fernandes, F. S. Lima, D. Rodrigues et al., "Evaluation of the isoflavone and total phenolic contents of kefir-fermented soymilk storage and after the in vitro digestive system simulation," Food Chemistry, vol. 229, pp. 373-380, 2017.

[21] K. Sharma, E. Y. Ko, A. D. Assefa et al., "Temperature-dependent studies on the total phenolics, flavonoids, antioxidant activities, and sugar content in six onion varieties," Journal of Food and Drug Analysis, vol. 23, no. 2, pp. 243-252, 2015.

[22] T. Masuko, A. Minami, N. Iwasaki, T. Majima, S.-I. Nishimura, and Y. C. Lee, "Carbohydrate analysis by a phenol-sulfuric acid method in microplate format," Analytical Biochemistry, vol. 339, no. 1, pp. 69-72, 2005.

[23] T. Seal, "Quantitative HPLC analysis of phenolic acids, flavonoids and ascorbic acid in four different solvent extracts of two wild edible leaves, Sonchus arvensis and Oenanthe linearis of North-Eastern region in India," Journal of Applied Pharmaceutical Science, vol. 6, no. 2, pp. 157-166, 2016.

[24] P. Batra and A. K. Sharma, "Anti-cancer potential of flavonoids: recent trends and future perspectives," 3 Biotech, vol. 3 , no. 6, pp. 439-459, 2013.

[25] A.-W. Zheng, Y.-Q. Chen, J. Fang, Y.-L. Zhang, and D.-D. Jia, "Xiaoaiping combined with cisplatin can inhibit proliferation and invasion and induce cell cycle arrest and apoptosis in human ovarian cancer cell lines," Biomedicine \& Pharmacotherapy, vol. 89, pp. 1172-1177, 2017.

[26] S. K. Vemuri, R. R. Banala, G. P. V. Subbaiah, S. K. Srivastava, A. V. G. Reddy, and T. Malarvili, "Anti-cancer potential of a mix of natural extracts of turmeric, ginger and garlic: a cellbased study," Egyptian Journal of Basic and Applied Sciences, vol. 4, no. 4, pp. 332-344, 2017.

[27] R. Jarial, A. Shard, S. Thakur et al., "Characterization of flavonoids from fern Cheilanthes tenuifolia and evaluation of antioxidant, antimicrobial and anticancer activities," Journal of King Saud University-Science, vol. 30, no. 4, pp. 425-432, 2018.

[28] J. Dai, P. G. Van Wie, L. Y. Fai et al., "Downregulation of NEDD9 by apigenin suppresses migration, invasion, and metastasis of colorectal cancer cells," Toxicology and Applied Pharmacology, vol. 311, pp. 106-112, 2016.

[29] J. Zhang Y. Wu, X. Zhao et al., "Chemopreventive effect of flavonoids from Ougan (Citrus reticulata cv. Suavissima) fruit against cancer cell proliferation and migration," Journal of Functional Foods, vol. 10, pp. 511-519, 2014.

[30] A. Tedasen, S. Sukrong, B. Sritularak, T. Srisawat, and P. Graidist, "5,7,4四-Trihydroxy-6,8-diprenylisoflavone and lupalbigenin, active components of Derris scandens, induce cell death on breast cancer cell lines," Biomedicine \& Pharmacotherapy, vol. 81, pp. 235-241, 2016.

[31] J. Liu, H. Wang, J. Wang et al., "Total flavonoid aglycones extract in Radix Scutellariae induces cross-regulation between autophagy and apoptosis in pancreatic cancer cells," Journal of Ethnopharmacology, vol. 235, pp. 133-140, 2019.

[32] A. Palko-Łabuz, K. Środa-Pomianek, O. Wesołowska, E. Kostrzewa-Susłow, A. Uryga, and K. Michalak, "MDR reversal and pro-apoptotic effects of statins and statins combined with flavonoids in colon cancer cells," Biomedicine \& Pharmacotherapy, vol. 109, pp. 1511-1522, 2019.

[33] N. L. Vukovic, A. D. Obradovic, M. D. Vukic, D. Jovanovic, and P. M. Djurdjevic, "Cytotoxic, proapoptotic and antioxidative potential of flavonoids isolated from propolis against colon (HCT-116) and breast (MDA-MB-231) cancer cell lines," Food Research International, vol. 106, pp. 71-80, 2018.

[34] Y.-Z. Zheng, G. Deng, D.-F. Chen, R. Guo, and R.-C. Lai, “The influence of $\mathrm{C} 2=\mathrm{C} 3$ double bond on the antiradical activity of flavonoid: different mechanisms analysis," Phytochemistry, vol. 157, pp. 1-7, 2019.

[35] S.-S. Tian, F.-S. Jiang, K. Zhang et al., "Flavonoids from the leaves of Carya cathayensis Sarg. inhibit vascular endothelial growth factor-induced angiogenesis," Fitoterapia, vol. 92, pp. 34-40, 2014.

[36] M. Zang, L. Hu, B. Zhang et al., "Luteolin suppresses angiogenesis and vasculogenic mimicry formation through inhibiting Notch1-VEGF signaling in gastric cancer," Biochemical and Biophysical Research Communications, vol. 490, no. 3, pp. 913-919, 2017.

[37] O. A. Chat, M. H. Najar, M. A. Mir, G. M. Rather, and A. A. Dar, "Effects of surfactant micelles on solubilization and DPPH radical scavenging activity of Rutin," Journal of Colloid and Interface Science, vol. 355, no. 1, pp. 140-149, 2011.

[38] D. G. B. Krisnamurti, M. Louisa, E. Anggraeni, and S. I. Wanandi, "Drug efflux transporters are overexpressed in short-term tamoxifen-induced MCF7 breast cancer cells," Advances in Pharmacological Sciences, vol. 2016, Article ID 6702424, 6 pages, 2016.

[39] M. A. Baghdadi, F. A. Al-Abbasi, A. M. El-Halawany, A. H. Aseeri, and A. M. Al-Abd, "Anticancer profiling for coumarins and related O-naphthoquinones from mansonia gagei against solid tumor cells in vitro," Molecules, vol. 23, no. 5, 2018.

[40] P. Mutlu, S. Yalçin Azarkan, N. Taghavi Pourianazar, M. Yücel, and U. Gündüz, "Determination of the relationship between doxorubicin resistance and Wnt signaling pathway in HeLa and K562 cell lines," EXCLI Journal, vol. 17, pp. 386398, 2018.

[41] Y. Wang, J. Ren, Y. Liu et al., "Preparation and evaluation of folic acid modified succinylated gelatin micelles for targeted delivery of doxorubicin," Journal of Drug Delivery Science and Technology, vol. 46, pp. 400-407, 2018.

[42] D. Luong, P. Kesharwani, H. O. Alsaab et al., "Folic acid conjugated polymeric micelles loaded with a curcumin difluorinated analog for targeting cervical and ovarian cancers," Colloids and Surfaces B: Biointerfaces, vol. 157, pp. 490-502, 2017. 


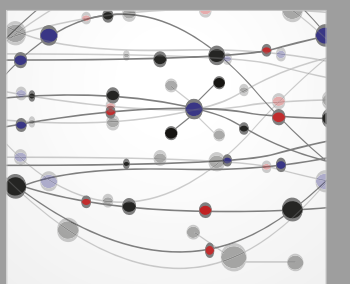

The Scientific World Journal
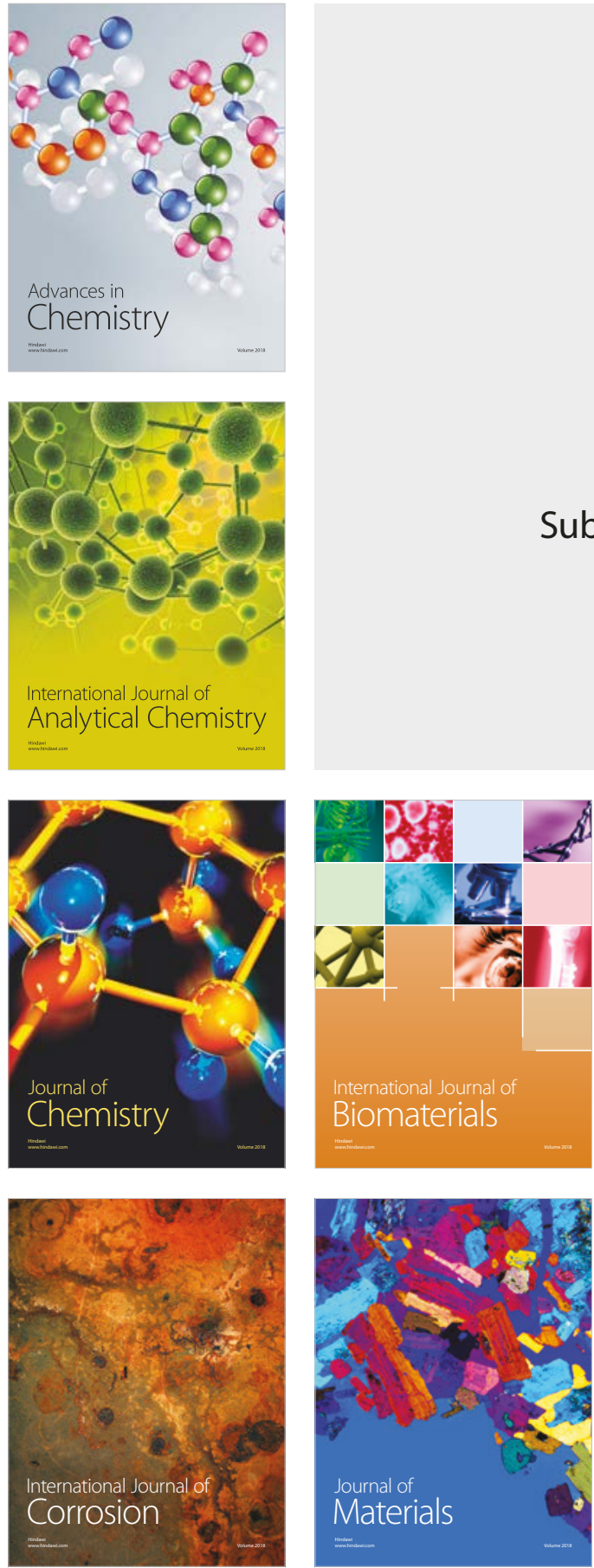

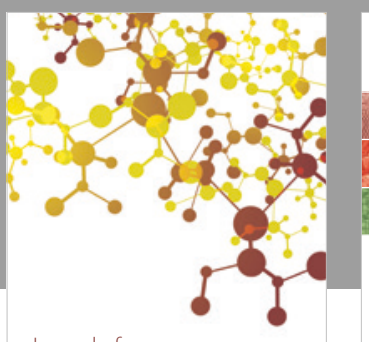

Journal of

Applied Chemistry
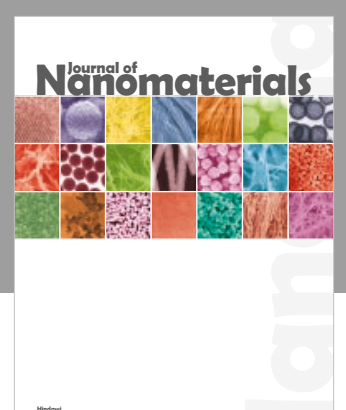

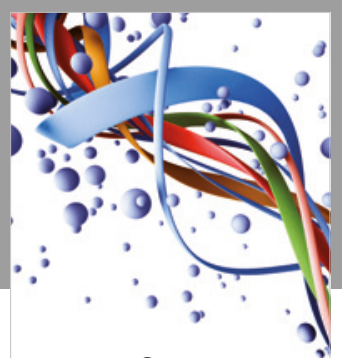

Scientifica

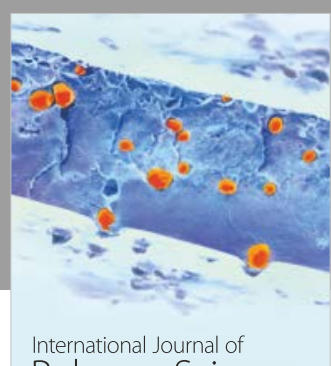

Polymer Science

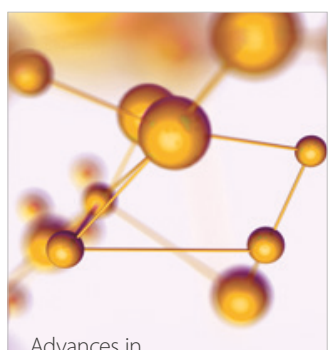

Physical Chemistry
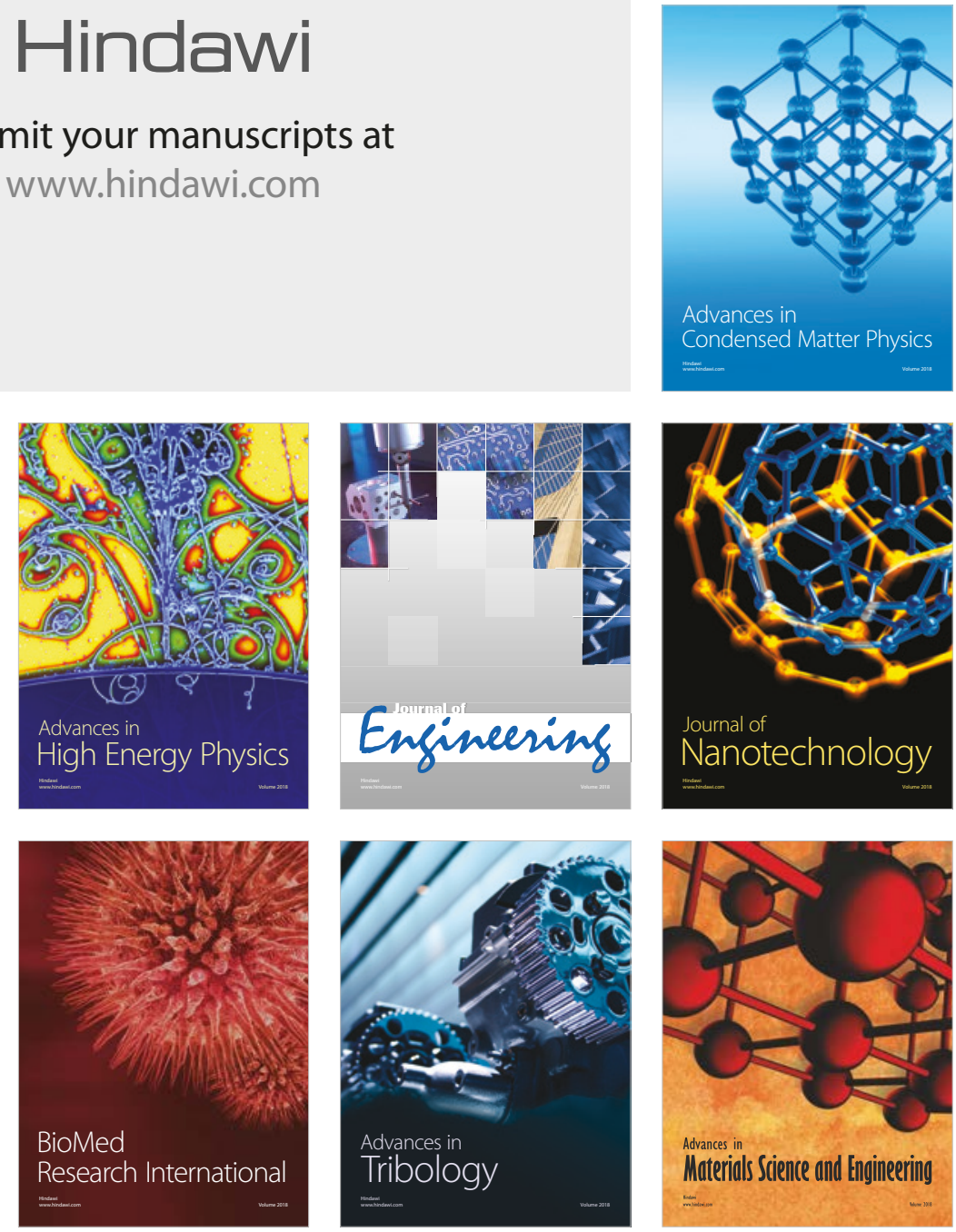